\begin{tabular}{|l|l|l|}
\hline \multicolumn{2}{|c|}{ PublisherInfo } \\
\hline \hline PublisherName & $:$ & BioMed Central \\
\hline \hline PublisherLocation & $:$ & London \\
\hline \hline PublisherImprintName & $:$ & BioMed Central \\
\hline \hline
\end{tabular}

\title{
PGE2-mediated repair of airway epithelium
}

\begin{tabular}{|l|l|l||}
\hline \multicolumn{2}{|c|}{ ArticleInfo } \\
\hline \hline ArticleID & $:$ & 1603 \\
\hline \hline ArticleDOI & $:$ & $10.1186 /$ rr-2001-68503 \\
\hline \hline ArticleCitationID & $:$ & 68503 \\
\hline \hline ArticleSequenceNumber & $:$ & 14 \\
\hline \hline ArticleCategory & $:$ & Paper Report \\
\hline \hline ArticleFirstPage & $:$ & 1 \\
\hline \hline ArticleLastPage & $:$ & 3 \\
\hline \hline & & RegistrationDate : 2001-4-27 \\
ArticleHistory & $:$ & Received \\
\hline \hline ArticleCopyright & $:$ & Biomed Central Ltd2001-9-14 \\
\hline \hline ArticleGrants & $:$ & \\
\hline \hline ArticleContext & $:$ & 129312211 \\
\hline \hline
\end{tabular}


Undurti Das, ${ }^{\text {Aff1 }}$

Corresponding Affiliation: Aff1

Aff1 EFA Sciences LLC, Norwood, MA, USA

\section{Keywords}

Bronchial asthma, prostaglandins, wound closure

\section{Context}

Following inflammatory and physical injury, the airway epithelium needs to be repaired for normal lung function to be restored. Epithelial regeneration involves spreading and migration of cells at the wound edge into the denuded surface to repopulate the wound site. Several factors, such as growth factors, extracellular matrix components and eicosanoids, seem to participate in this airway repair process. Prostaglandins are known to participate in wound healing processes in tissues such as skin, corneal epithelium, and intestinal epithelium. In view of this, the possible role of prostaglandins in regulation of airway epithelium wound closure was examined in this study.

\section{Significant findings}

In this in vitro study, the authors found that prostaglandin $\mathrm{E}_{2}\left(\mathrm{PGE}_{2}\right)$ stimulated wound closure in a dose-dependent fashion. Inhibitors of both cyclo-oxygenase (COX) 1 and 2 which convert arachidonic acid to prostanoids, reduced the rate of wound closure. $\mathrm{PGE}_{2}$ receptors are called E prostanoids 1-4 (EP1-EP4). Using agonists and antagonists, it was observed that PGE2 mediated its stimulatory action on wound healing through EP1 and EP4 but not through the EP3 receptor. Time course studies showed that prostaglandins are critical in the early stages of repair. Metabolites of 5-lipoxygenase did not seem to participate in this wound healing process. This study suggests that PGE2is important for airway epithelial wound healing, and assumes significance in light of the known actions of arachidonic acid and its metabolites in cell protection, growth, angiogenesis and extracellular matrix production.

\section{Comments}


This study suggests that $\mathrm{PGE}_{2}$ plays a critical role in wound closure in airway epithelium. Nonsteroidal anti-inflammatory drugs (NSAIDs) are frequently used by patients with asthma and other respiratory ailments, and these drugs are known to produce gastrointestinal mucosal damage. From the results of this study, it is clear that NSAIDs may also interfere with airway wound healing, since NSAIDs inhibit COX. Their use, therefore, needs to be monitored in patients with respiratory conditions. It remains to be seen whether NSAIDs interfere with wound healing induced by growth factors and how various growth factors and prostaglandins interact. More importantly, could inhalation of prostaglandins be used to enhance wound closure in the airway epithelium?

\section{Methods}

Human and feline primary tracheal and bronchial epithelial cells, immunoblotting for COX enzymes

\section{Additional information}

\section{References}

1. Salva U, Appel HJ, Sporn PHS, Waters CM: Prostaglandin E2regulates wound closure in airway epithelium. Am J Physiol Lung Cell Mol Physiol . 2001, 280: L421-L431. 